\title{
СТАРООБРЯДЧЕСТВО ХІХ - НАЧАЛА ХХ В. КАК ТИП СОЦИАЛЬНОЙ ОБЩНОСТИ: ВНУТРЕННИЕ И ВНЕШНИЕ ГРАНИЦЫ (ПО МАТЕРИАЛАМ ХАРЬКОВСКОЙ ГУБЕРНИИ)
}

\section{П. В. Еремеев}

Сремєєв П. В. Старообрядництво XIX - початку XX ст. як тип соціальної спільноти: внутрішні та зовнішні межі (за матеріалами Харківської губернії). У статті здійснена спроба охарактеризувати старообрядницьке населення Харківщини як тип соціальної спільноти. Показано, що старообрядницьке населення Російської імперії являло собою умовну соціальну спільноту, що складалася із великих соціальних груп - згод. Їхніми структурними елементами були старообрядницькі общини (малі та середні соціальні групи). Характеризуються внутрішні та зовнішні межі старообрядництва, аналізується взаємовплив старовір'я та раціоналістичного сектантства у Харківському регіоні, показаний вплив практик приховування віри на внутрішню структуру старообрядницьких общин.

Ключові слова: старообрядці; згоди; Харківська губернія; соціальна спільнота; уявлені спільноти; сектантство; приховування віри.

Еремеев П. В. Старообрядчество XIX - начала XX в. как тип социальной общности: внутренние и внешние границы (по материалам Харьковской губернии). В статье предпринята попытка охарактеризовать старообрядческое население Харьковской губернии как тип социальной общности. Показано, что старообрядчество Российской империи представляло собой условную социальную общность, состоящую из больших социальных групп - согласий. Их структурными частями были староверческие общины (малые и средние социальные группы). В статье охарактеризованы внутренние и внешние границы старообрядчества, анализируется взаимовлияние староверия и рационалистического сектантства в Харьковском регионе, показано влияние практик сокрытия веры на внутреннюю структуру старообрядческих общин.

Ключевые слова: старообрядцы; согласия; Харьковская губерния; социальная общность; воображаемые сообщества; сектантство; сокрытие веры.

Eremeev $P$. $V$. The Old Belief in the $19^{\text {th }}$ - early $20^{\text {th }}$ century as a type of social community: internal and external borders (the case of Kharkiv province). The paper deals with the Old Believed population of Kharkiv province as a type of community. It is proved that the Old Belief in Russia was a social category, which consisted of the large groups - concords. The Old Believers' communities as primary and secondary groups were structural elements of concords. In the article the internal and external borders of the Old Belief are characterized, the mutual influence of the Old Belief and rational sectarianism in Kharkiv province is analyzed and the impact of the faith concealment by the Old Believers on their communities' social structure is shown.

Keywords: Old Believers; concords; Kharkiv province; social community; imagined community; sectarianism; concealment of faith.

Старообрядчество как особый общественный феномен довольно рано стало привлекать к себе внимание исследователей. Уже в миссионерских трудах XVIII в. были осуществлены первые попытки определить характер социальных связей внутри старообрядческого сообщества ${ }^{1}$. С середины XIX в. к этому вопросу стали активно обращаться светские исследователи. Начали предприниматься попытки охарактеризовать внутренние и внешние границы старообрядчества, в частности, выяснить, существовало ли жёсткое разделение между староверием и другими направлениями русского религиозного диссидентства, определить уровень внутриконфессиональной дифференциации внутри «старой веры» ${ }^{2}$. При этом ответы исследователей на данные вопросы нередко противоречили друг другу.

На современном этапе данный вопрос приобретает особую актуальность, ведь интересы социогуманитарных наук все больше сосредотачиваются на «границах» различных общественных и культурных сущностей (языков, культур, стран и т.д.) ${ }^{3}$. На новом методологическом уровне поставлена и проблема определения внешних и внутренних границ староверия ${ }^{4}$. Однако, как признает известный современный религиовед Е.И. Аринин, границы старообрядчества до сих пор остаются недостаточно очерченными констатировать кризис подходов, в основе которых лежит стремление охарактеризовать 
социальную организацию старообрядческого сообщества на основе произвольно избранных признаков, используя крайне нечёткие, скорее художественные, чем научные определения («извилистая граница», «изолированные миры», «переходной оттенок», «гармоничное целое», «точки идеологического пересечения», «чёткость примыкания» и т.д.). Назрела необходимость исследования, в котором на основе современных междисциплинарных подходов структура старообрядческого сообщества, его внутренние и внешние границы будут охарактеризованы в чётких дефинициях, выработанных в рамках социологии и религиоведения. При этом, исходя из признания базисного для трансдисциплинарных стратегий тезиса о существовании различных уровней реальности ${ }^{6}$, следует учитывать теоретически сформулированное старообрядческой элитой мировосприятие, бытовые представления, нормы и практики староверов, общественные связи различных уровней.

Нами была предпринята попытка установить типы социальных общностей, к которым принадлежало старообрядчество Харьковской губернии и его отдельные группы в XIX начале XX вв. Изучение социальной структуры старообрядческой общности в масштабах отдельного региона позволяет анализировать проблему на различных уровнях, реализуя выработанный в рамках «новой социальной истории» принцип «игры масштабами», сочетая элементы микро- и микроанализа. В Харьковской (до 1835 г. - Слободско-Украинской) губернии существовали давние старообрядческие традиции, были распространены различные направления старообрядчества и сектантства, что позволяет исследовать вопрос о взаимопроникновении этих двух течений религиозной оппозиции, анализировать влияние субконфессиональных различий на социальную структуру старообрядческого населения.

Источниковой базой исследования стали статистические источники (в частности, материалы переписи 1897 г.), миссионерские отчеты, уголовные дела против староверов, жалобы и ходатайства старообрядцев в органы государственной власти. Часть из указанных источников опубликована, часть хранится в фондах Государственного архива Харьковской области и Российского государственного исторического архива.

Следует отметить, что характеристика сущности понятия «старообрядчество» является отдельной научной проблемой. В качестве рабочей дефиниции воспользуемся определением М.О. Шахова: старообрядчество - это общее название духовенства и мирян, которые не признают реформу в Русской Православной Церкви, осуществлённую в середине XVII в. патриархом Никоном, суть которой заключалась в приближении русских обрядов и богослужебных текстов к греческим образцам. Среди староверов сложилось несколько религиозных организаций (так называемых толков и согласий), каждая из которых считает себя истинной Православной Церковью7.

В современной социологии выделяют различные типы социальных общностей. Наиболее общим является их разделение на реальные и условные (номинальные). Первые являются «совокупностями индивидов, характеризующихся относительной целостностью, выступают как самостоятельный субъект исторического и социального действия и поведения», то есть, они существуют реально, а не являются лишь абстракциями, созданными для анализа общественной жизни. Вторые, наоборот, выделяются произвольно, на основе общих черт, выделенных внешним наблюдателем. В условных общностях отсутствуют обязательные связи, поэтому некоторые социологи вообще не называют их общностями в прямом смысле этого слова (Я. Щепанский использует термин «социальное множество») ${ }^{8}$.

Старообрядчество в целом не может считаться реальной социальной общностью, ведь почти с самого начала своего существования староверие не было идеологически единым, причём староверы разных согласий отрицали православность друг друга, считая истиной Церковью только собственное согласие. Единой старообрядческой идентичности, не говоря уже об организационном единстве, не сложилось ${ }^{9}$. На материалах Харьковской губернии также не прослеживается регулярного взаимодействия между старообрядцами разных согласий.

Таким образом, совокупность различных религиозных групп, объединяемых термином «старообрядчество», может быть охарактеризована как социальная категория. Под социальной категорией в социологии понимается вид социального множества (или условной социальной общности), выделение которого осуществляется на основе некоей общей черты, присущей определенной совокупности индивидов (одной из этих черт может быть вероисповедание $)^{10}$. Конечно, на всероссийском уровне имели место факты взаимодействия различных старообрядческих согласий ${ }^{11}$, велась постоянная полемика между их предста- 
вителями, предпринимались попытки объединений (как правило, безуспешные) ${ }^{12}$. Более того, в начале XX в. среди части старообрядческой интеллигенции стали циркулировать идеи старообрядческого единства ${ }^{13}$.

Всё это позволяет говорить о том, что старообрядческая элита находилась в одном интеллектуальном поле, в рамках которого происходило активное умственное взаимодействие как в пространстве (между современниками), так и во времени (с предшественниками). При этом общее интеллектуальное поле старообрядческих лидеров имело тенденции к превращению в дискурсивное, в котором словесное взаимодействие трансформируется в определенный тип социальной практики ${ }^{14}$. Однако указанные факты не вступают в противоречие с тезисом о старообрядчестве, как об условной социальной общности. Как отмечает С.С. Новикова, некоторые условные общности очень близки к реальным, им бывают свойственны сплочённость и контактность, если признак, по которому происходит распределение людей, является существенным ${ }^{15}$. Именно это мы видим в случае со старообрядчеством. Но уровень взаимодействия старообрядческих согласий не позволяет говорить, что старообрядчество в период до 1917 г. превратилось из социальной категории в реальную социальную общность. Имели место отдельные тенденции в этом направлении.

Гораздо лучше под определение реальной социальной общности подходят старообрядческие согласия - объединения верующих, придерживающихся той или иной разновидности обрядовой практики ${ }^{16}$ (а в случае со старообрядчеством это неотделимо от тех или иных интерпретаций вероучения). Старообрядчество практически никогда не было организационно и идейно единым. На уровне теоретически сформулированных религиозных идей практически во всех старообрядческих согласиях существовало представление о своей конфессии как единственной истинной Церкви Христовой. Другие же направления староверия воспринимались как раскольнические или еретические группировки ${ }^{17}$. Но возникает вопрос, насколько глубоко это представление проникало в старообрядческие массы? Соответственно, насколько осознанным среди староверов было ощущение сопричастности с членами своего согласия и обособленности от представителей других направлений старообрядчества?

При ответе на данный вопрос мы опирались на концепцию Б. Андерсона, в соответствии с которой «любое сообщество, большее первоначального поселения с непосредственным контактом между жителями (хотя, возможно, и оно) является воображаемым» ${ }^{18}$. Воображаемым в том смысле, что его представители никогда не будут знать большинства членов этого сообщества, даже не будут слышать о них. И все же, в воображении каждого из них будет жить образ своей сопричастности с членами этого сообщества. При этом, как отмечает Б. Андерсон, «манера представления» сопричастности лица с определенной группой людей в разные периоды была очень разной. Исходя из этих положений, мы попытались выяснить, каким образом происходило представление согласия его членами, как различные группы староверов воспринимали границы своей религиозной группы.

Имеющиеся источники позволяют утверждать, что среди многих старообрядцев Харьковского региона представления о границах своего согласия были размытыми. Так, в ходе Первой всероссийской переписи населения 1897 г. в Харьковской губернии из 7118 «старообрядцев и тех, кто уклонился от православия» 4554 (64\%) не указали своего согласия. Харьковщина в этом отношении не была уникальной. В целом по империи, по данным переписи, доля лиц, не указавших своё согласие среди «старообрядцев и тех, кто уклонился от православия» составляла $45 \%{ }^{19}$.

Похожая ситуация наблюдается в некоторых старообрядческих общинах и в наше время. Так, проведенный в 1970-е гг. Л.Ю. Брацлавским опрос среди старообрядцев Чувашии показал, что многие из них не знали, к какому согласию принадлежат ${ }^{20}$. Пентикяйнен приводит характерное высказывание старообрядца-беспоповца Амвросия Сидорова, записанное в 1991 г. в одном из населенных пунктов Балтийского региона: «У нас три церкви: православная, старообрядческая и федосеевская $»^{21}$. С канонической точки зрения такое высказывание является абсурдом. И поморцы (именно их молитвенный дом Амвросий Сидоров называл старообрядческим), и федосеевцы на уровне теоретически сформулированных положений своей веры считают себя православными старообрядцами. Приведенная цитата позволяет сделать вывод о размытости бытовых представлений некоторых староверов о сущности конфессиональных границ внутри старообрядчества. Судя по данным переписи 1897 г., в конце XIX в. подобная размы- 
тость представлений о собственной конфессиональной идентичности была очень распространенной среди рядовых староверов.

Стоит также отметить, что далеко не всегда следование своей вере было выражением чётко осознанных экклезиологических идей. М.П. Гиляров-Платонов, характеризуя особенности религиозной идентичности населения Российской империи XIX в., отмечал, что догматы малоизвестны народным массам, принадлежность к определенной церкви является, скорее, обычаем, принадлежностью быта. Разница лишь в том, что в вероисповедании к простому обычаю добавляется представление, однако не везде ясное и достаточно прочное, что «в этой вере спасешься» 22 . Современный исследователь старообрядчества А.А. Пригарин указывает, что среди староверов Придунавья следование «старой вере» нередко было «порождено скорее традиционализмом, чем сознательным предпочтением» ${ }^{23}$.

Подобное восприятие своей веры имело место и среди старообрядцев Харьковской губернии. Миссионер Змиевского уезда священник Давид Антонов в рапорте от 1889 г. указывал, что на его аргументы о невозможности спасения вне истинной Церкви и предложения перейти в РПЦ местные старообрядцы отвечали: «Что будет, то будет, а мы будем спасаться так, как спасались наши отцы и деды» ${ }^{24}$. В составленном Харьковским епархиальным советом по миссионерским делам «Отчёте о состоянии противораскольнической и противосектантской миссии за 1900 г.» указывается, что старообрядцы села Граково на предложение миссионера пообщаться отвечали: «Приезжали к нам ваши попы и протопопы, и что же - многих отклонили от родительской веры, нам от них завещанной» ${ }^{25}$. То есть, именно унаследованность веры была главным аргументом в её пользу. В том же отчёте относительно старообрядцев Купянского уезда указывается: «Все они безграмотные и не имеют никаких познаний в вопросах веры, так верили их родители и деды» ${ }^{26}$. В миссионерском отчете за 1906 г. также отмечалось, что когда православные начинали разговор со старообрядцами о предметах веры, те, как правило, отвечали: «Так жили и верили наши отцы, так и мы будем жить» ${ }^{27}$.

Конечно, можно поставить под сомнение сведения и, особенно, оценки миссионеров. Изображение старообрядчества как явления, которое не имеет будущего и держится на упрямстве своих членов, было характерной чертой миссионерского дискурса того времени. И действительно, вышеприведенные свидетельства позволяли миссионерам сделать вывод, что старообрядчество в целом представляет собой «малоподвижную, тёмную, но упорную в необразованности своей массу» ${ }^{28}$. Однако, признавая влияние доминирующего дискурса на оценки, содержащиеся в миссионерских отчетах, тем не менее, к ним нельзя подходить исключительно с интертекстуалистских позиций. А. Эткинд, исследуя образ религиозного диссидентства в русской литературе на рубеже XIX-XX вв., исходил из презумпции интертекстуальности ${ }^{29}$. Это действительно логично, когда мы имеем дело с текстами, которые написаны людьми, профессионально связанными с литературой. Но миссионерские отчеты писались теми, кто на практике постоянно сталкивался со старообрядцами и сектантами. Конечно, господствовавший дискурс обуславливал определенные акценты в интерпретации тех или иных явлений, однако сводить все оценки миссионеров только к этому, по нашему мнению, некорректно. Следует отметить, что, несмотря на общую склонность миссионеров изображать старообрядцев упрямыми и невежественными, они отдавали должное интеллектуальному уровню отдельных наставников. В частности, в отчёте за 1906 г. наставник старообрядческой общины села Ольховатка Стефан Орлов охарактеризован как «сравнительно начитанный» ${ }^{30}$. Наставник старообрядцев-беспоповцев села Трёхизбянка Иоанн Орлов описан как «грамотный и умный, но упрямый раскольник» ${ }^{31}$.

Что же касается восприятия старообрядцами своей веры, прежде всего, как веры родителей, об этом свидетельствуют не только миссионерские отчеты, но и тексты, написанные самими староверами или записанные за ними. Так, в 1835 г. старообрядцы селений Уды, Лопань и хутора Казачка Харьковского уезда в беседе с уездным судьей Войтенковым заявили, что принадлежат к Поморскому согласию «по преданию предков их» ${ }^{32} .11$ марта 1858 г. 65 крестьян слободы Краснянка заявили в сельской управе, что они «возвращаются к своей изначальной старообрядческой беспоповской вере, в которой они, их отцы и матери находились» ${ }^{33}$. В 1863 г. крестьяне хутора Ямполь Волчанского уезда заявили, что они в связи с выходом «царского манифеста» решили вернуться к вере предков (старообрядчеству $)^{34}$. Представляется, что в этой акцентуации на наследуемости веры проявилось не только желание старообрядцев представить себя как «природных раскольников», то есть 
таких, которые имеют право исповедовать «старую веру», но и убеждения в необходимости следовать именно родительской вере и именно потому, что она - от предков.

Данные о размытости экклезиологических представлений многих старообрядцев на Харьковщине содержатся и в «Историко-статистическом описании Харьковской епархии» архиепископа Филарета (Гумилевского). Характеризуя мировоззрение некоторых жителей г. Чугуева, владыка Филарет писал: «Многие считали за одно церковь и раскол; переходить от первой к последнему, равно как и наоборот, было для иных одно и то же, молиться в Православной церкви и ходить для молитвы в раскольнические часовни почитали делом совершенно безразличным» ${ }^{35}$. В миссионерском отчете за 1900 г. отмечалось, что староверы селений Охочее и Берек в православный храм не ходят, но к духовенству РПЦ относятся с уважением, радостно принимают его с молитвой и святой водой ${ }^{36}$. В 1906 г. миссионеры отмечали, что в некоторых общинах старообрядцы «отходят от своих прежних недоверия и подозрительности к православным священникам, вступают с ними в разговоры, принимают от них благословение ... подают в храм просфоры и свечи» ${ }^{37}$.

Конечно, и в этих свидетельствах миссионеров чувствуется общее влияние господствующего дискурса. Но в случаях, когда старообрядцы тех или иных общин не шли на контакты с православным духовенством, демонстрировали высокий уровень понимания своей веры, это находило отражение в тех же отчётах. Так, в рапорте миссионера Северина Сулимы за 1878 г. отмечалось, что в хуторе Казачка все старообрядцы, даже женщины, готовы отстаивать свое учение ${ }^{38}$. Относительно старообрядцев Змиевского уезда миссионеры писали, что они «упорно держатся раскола»39. В отчёте за 1906 г. указывается, что наряду со старообрядческими общинами, в которых наблюдается улучшение отношения к православным, существуют и такие, в которых староверы «особенно замкнуты» ${ }^{40}$. Итак, если ситуация, которую наблюдали миссионеры на местах, вступала в противоречие с общей тенденцией изображать старообрядчество как явление, которое постепенно ослабляется, это находило отражение в отчётах. Поэтому и свидетельства об ограниченном участии старообрядцев некоторых общин в молитвенных действиях с участием духовенства РПЦ также заслуживают доверия.

Следует отметить, что указанная практика существовала не только среди старообрядцев Харьковщины. О подобном писали миссионеры Олонецкой, Черниговской, Курской губерний ${ }^{41}$.

Участие старообрядцев в совместной молитве со священниками РПЦ с точки зрения теоретически сформулированного старообрядческого мировоззрения недопустимо, ведь для староверов члены господствующей Церкви - еретики. В десятом Апостольском правиле сказано: «Если кто с отлученным от общения церковного помолится, хотя бы то было в доме: такой да будет отлучен» ${ }^{42}$. Таким образом, мы снова имеем дело с разницей между теоретически сформулированным старообрядческим мировоззрением с одной стороны, и бытовым восприятием и повседневными практиками - с другой.

Итак, в XIX - начале XX вв. представления многих старообрядцев Харьковской губернии о своей принадлежности к тому или иному согласию, его границах и экклезиологической сущности, были довольно размытыми. Это и не удивительно, ведь среди староверов XIX - начала XX вв. далеко не все умели читать и писать. По данным переписи 1897 г. в Харьковской губернии среди старообрядцев всех сословий доля грамотных составляла $20 \%{ }^{43}$. Это несколько больше, по сравнению с православным населением региона (среди чад РПЦ в Харьковской губернии в 1897 г. грамотных насчитывалось 16\% $)^{44}$. И подобная ситуация не была уникальной: среди староверов всей Российской империи доля образованных людей также была выше, чем среди православных ${ }^{45}$. Кроме того, до конца неясно, что стояло за формулировками «грамотный» и «неграмотный» в материалах Первой всероссийской переписи. Дело в том, что чиновники Российской империи неграмотным могли считать человека, владеющего навыками чтения и письма на старославянском языке, но не знакомого с гражданским шрифтом (а среди староверов таковых было немало) ${ }^{46}$. Да и сами староверы в подобной ситуации могли называть себя необразованными. Так, письмо одной старообрядки, написанное полууставом в 1974 г. и адресованное выдающемуся археографу И.В. Поздеевой, начинается словами: «Прости, Васильевна, по-русски писать не умею, пишу как учили» ${ }^{47}$. Поэтому вполне вероятно, что реальный уровень грамотности среди староверов Харьковского региона в конце XIX в. был выше, чем это показали результаты переписи 1897 г. Однако, несмотря на приведенные соображения, результаты пе- 
реписи 1897 г. не дают оснований говорить о всеобщей грамотности среди старообрядцев Российской империи вообще и Харьковской губернии в частности. Можно согласиться с Е.А. Мельниковой, которая отметила, что тезис о чрезвычайной образованности староверов Российской империи является достаточно спорным, он основан на сложившемся в литературе XIX в. идеализированном образе старообрядчества ${ }^{48}$.

Кроме того, хотя в среде старообрядцев активно писали и печатали полемическую литературу, в том числе и с критикой других согласий ${ }^{49}$, в основном, в круг чтения образованного старообрядца входила традиционная богослужебная литература, поучения и наставления святых отцов и т.д. ${ }^{50}$ Такая литература является общей для всех старообрядческих согласий, поэтому она не формировала у читателей жёсткой конфессиональной идентичности. Понятно, что в такой ситуации представления многих старообрядцев о конфессиональных границах внутри староверия, своей принадлежности к тому или иному согласию были размытыми. Особенно, если определенная старообрядческая община не имела регулярных контактов с представителями других согласий.

Тем не менее, старообрядческие согласия XIX - начала XX вв. можно рассматривать как воображаемые сообщества, хотя и отличные от сообществ «горизонтально-секулярного, поперечно-временного типа», каковыми являются современные нации ${ }^{51}$. Характер представления старообрядцев о своём согласии можно назвать «двухуровневым». Многие рядовые староверы имели размытые представления о своей принадлежности к тому или иному направлению «старой веры». Но все они принадлежали к определенной старообрядческой общине, в которой связь членов была очень сильной ${ }^{52}$. Духовная же элита общины (в случае с беспоповцами - наставники, уставщики, начетчики, просто образованные миряне, в случае с поповцами - ещё и священники) и на уровне собственных представлений, и на уровне практического взаимодействия обеспечивала воображаемое и организационное единство согласия, связь между различными общинами одного согласия. Идею о ключевой роли лидеров конкретных старообрядческих общин в поддержании единства древлеправославных согласий высказывал Р. Крамми ${ }^{53}$. На локальном харьковском материале эта идея получает полное подтверждение.

Имеющиеся источники содержат информацию, которая позволяет сделать вывод о достаточно сильном влиянии духовной элиты старообрядческих общин на рядовых староверов. Так, исполняющий обязанности Харьковского уездного предводителя дворянства судья Войтенков в рапорте губернатору П.И. Трубецкому от 8 июля 1835 г. отмечал, что в случае, если старообрядцев-беспоповцев села Лопань изолировать от наставника Тимофея Дигалова, есть основания надеяться на их переход в РПЦ54. В 1836 г. священник села Ивановки Змиевского уезда Алексей Крахмалов в рапорте архиепископу Мелетию указывал, что одной из главных причин отсутствия успеха православной проповеди среди старообрядцев хутора Гусинского является противодействие их наставника Василия Енохина ${ }^{55}$. Характерен пример старообрядческих общин в Бабчанском и Пятницком приходах Волчанского уезда. В них в конце XIX в. обязанности наставника исполнял отставной солдат Бунаков из селения Зарожное, который, вследствие удаленности общин, довольно редко контактировал с ними. В результате, в этих поселках, по свидетельству миссионеров, старообрядчество было слабее, чем в целом по епархии. Более того, в связи с удалённостью старообрядческой часовни староверы Бабчанского и Пятницкого приходов нередко приносили крестить своих детей к священникам РПЦ ${ }^{56}$. В «Отчете о состоянии противораскольнической и противосектантской миссии за 1900 г.» указывается, что староверы-беспоповцы г. Чугуева и его окрестностей «имеют руководителей-начетчиков, которыми и поддерживаются в расколе» ${ }^{57}$. Относительно старообрядцев-поповцев Старобельского уезда в том же отчете отмечается: «Местные раскольники [...] держатся упорством невежественных главарей» ${ }^{58}$.

При этом духовная элита старообрядческих общин Харьковской губернии обеспечивала связь между различными общинами одного согласия. В собранных Канцелярией Харьковского губернатора в 1826 г. сведениях о старообрядческих часовнях и молитвенных домах указывается, что трое из наставников старообрядцев-беспоповцев Харьковской губернии (Филипп Орлов в хуторе Чугуновом, Прокофий Шевяков в хуторе Шевяковке и Максим Алипов в хуторе Грачёвом) учились в Москве, причём последний из Москвы также получал иконы и уставные книги для своей часовни ${ }^{59}$. В Волчанском уезде в начале $\mathrm{XX}$ в. большим авторитетом среди староверов пользовался наставник села Ольховатки Стефан Орлов. Согласно данным миссионерских отчетов того времени он поддерживал контакты с беспопов- 
скими лидерами других губерний, давал советы начетчикам других харьковских общин ${ }^{60}$. В 1913 г. в Харькове состоялся съезд старообрядцев Поморского согласия. На съезде, кроме харьковских поморцев, присутствовали их единоверцы из Москвы и Пскова ${ }^{61}$.

Среди поповцев Харьковской губернии роль конфессиональной элиты в обеспечении единства согласия была, возможно, еще большей. Ведь в условиях государственного давления поповцы ощущали нехватку собственного духовенства. Поэтому имеющиеся священники, как правило, обслуживали по нескольку общин, что усиливало ощущение их единства и взаимосвязи ${ }^{62}$. Правда, в 1827 г. старообрядческим священникам было запрещено переходить из уезда в уезд и из губернии в губернию ${ }^{63}$. Однако, во-первых, подобные запреты нередко удавалось обойти. Как сообщал миссионер Северин Сулима в отчете за 1878 г., «те секты, которые не отрицают священства, принимают самозваных (т.е. старообрядческих - П. Е.) попов, которые секретно посещают раскольнические поселения под видом офеней» ${ }^{64}$. Во-вторых, для выполнения своих религиозных обрядов (например, венчаний) старообрядцы ездили в те населенные пункты, где были священники.

Все это, опять-таки, способствовало усилению единства внутри согласия. Организационное единство поповских общин Харьковской губернии усилилось после основания Белокриницкой иерархии и её принятия поповцами региона. Теперь у них появился центр, которому они подчинялись не только исходя из авторитета и влияния последнего, но и в связи с церковно-каноническими соображениями. В духовно-административном отношении поповцы Харьковской губернии стали подчиняться Московской старообрядческой архиепископии ${ }^{65}$. При этом старообрядческое духовенство продолжало обслуживать по нескольку общин. В конце XIX в. старообрядческие священники, в основном, проживали за пределами Харьковской епархии (в Екатеринославской губернии и в Области войска Донского) и периодически наведывались в регион ${ }^{66}$.

По данным Харьковского епархиального совета по миссионерским делам, в регионе по состоянию на 1906 г. было три старообрядческих прихода с «попами»: в Харькове, селе Краснянка Купянского уезда и селе Нижне-Богдановка Старобельского уезда. При этом поповцы проживали и во многих других населённых пунктах Харьковской губернии ${ }^{67}$. Конечно, возможно миссионеры просто не знали о наличии старообрядческих священнослужителей в некоторых приходах. Но вряд ли священники-старообрядцы были во всех населенных пунктах, в которых проживали поповцы. Поэтому старообрядческое духовенство сохраняло мобильность, продолжало обслуживать по нескольку общин. Кроме того, по данным исполняющего обязанности миссионера Старобельского уезда, священника Алексея Грекова, в конце XIX в. регион посещали старообрядческие архиереи ${ }^{68}$. Сохраняли активность и миряне. Тот же миссионер Алексей Греков писал, что «раскол поддерживают главные вожаки - московские купцы-раскольники, которые с этой целью приезжают ежегодно в слободу Беловодск на ярмарку» ${ }^{69}$. Всё это способствовало формированию чувства единства среди членов согласия.

Это не означает, что в воображении всех лидеров старообрядческих общин существовал четко сформированный образ согласия, причём этот образ всегда полностью совпадал с теоретически сформулированным в старообрядческой литературе пониманием своего согласия как единственной Церкви Христовой, с границами, определенными православным каноном. Отчёты священников РПЦ содержат информацию не только об активных и образованных старообрядческих наставниках Харьковской губернии, таких, как Иоанн Небесный (охарактеризованный как «грамотный и толковый» в сведениях о раскольниках слободы Райгородка) ${ }^{70}$, Стефан Орлов и Пётр Гурьев (охарактеризованные в миссионерском отчёте за 1907 г. как «относительно начитанные») ${ }^{71}$. Нередко лидеры старообрядческих общин характеризуются как «грубые и невежественные», неспособные сформулировать своё вероучение (например, начётчик Фёдор Губанов) ${ }^{72}$. Не доверять этой характеристике нет оснований, ведь высокий уровень образованности некоторых старообрядческих наставников нашёл отражение в отчетах миссионеров РПЦ.

Отсутствие чётких представлений об экклезиологических границах своей конфессии у некоторых старообрядческих наставников Харьковщины нивелировалось описанными выше повседневными практиками взаимодействия между общинами одного согласия, а также иерархией внутри элиты, в том числе беспоповской (здесь можно вспомнить отмеченный выше факт обращения к Стефану Орлову наставников других общин губернии). Всё это создавало единую сеть общин, принадлежащих к одному согласию. 
Таким образом, именно старообрядческое согласие может быть охарактеризовано как реальная социальная общность. Все виды реальных социальных общностей можно разделить на два типа - массовые и групповые сообщества. Старообрядческое согласие имело все признаки групповой общности (социальной группы), отличаясь органическим характером (наличием целостности и внутренней структуры, которая не совпадала с простой суммой свойств элементов, в неё входящих), определенностью и устойчивостью границ, гомогенностью состава ${ }^{73}$. При этом, как большая групповая общность, все члены которой не знают друг друга в лицо и контакты между которыми не могут совершаться непосредственно, старообрядческое согласие состояло из общин, которые могут быть охарактеризованы как средние и малые группы.

Определение старообрядчества как социальной категории, в рамках которой существовали групповые социальные общности (согласия), позволяет по-новому посмотреть на вопрос о границах старообрядчества и других направлений русского религиозного инакомыслия (так называемого рационалистического и мистического сектантства). Казалось бы, выделение староверов как особой социальной категории основано на чётком критерии - принадлежности человека к старообрядчеству. Однако в историографии идут дискуссии относительно того, в какой мере старообрядчество и сектантство переплетались и влияли друг на друга на уровне повседневных практик, религиозных идей и т.д. Одни исследователи (П.И. Мельников, И.А. Кириллов) утверждают принципиальное отличие этих двух направлений русской религиозной оппозиции, их изолированность друг от друга ${ }^{74}$. Сторонники противоположной точки зрения (А. Эткинд, А. Панченко) считают бесперспективным противопоставление старообрядчества и сектантства, указывая, что внутри этих течений были значительные группы, которые взаимно тяготели друг к другу ${ }^{75}$. В качестве обоснования приводится использование некоторыми сектантами двуперстного крестного знамения, дониконовского варианта Иисусовой молитвы и других элементов культа, характерных для старообрядчества. Некоторые исследователи влиянием хлыстовства объясняют распространение среди старообрядцев практики самосожжений ${ }^{76}$.

Что касается границы между старообрядчеством и мистическим направлением старорусского сектантства (представленным сектами хлыстов и скопцов), на Харьковщине не прослеживается взаимодействия между ними, хотя оба религиозных течения были распространены в регионе. Возможно, это объясняется тем, что на территории Харьковской губернии существовали достаточно умеренные направления «старой веры» (поповщина и Поморское согласие беспоповщины). А взаимовлияние с мистическим сектантством, по мнению современных исследователей А.А. Панченко и А. Эткинда, было характерным для радикального крыла старообрядцев-беспоповцев (в частности, федосеевского, страннического и часовенного согласий $)^{77}$.

Более сложным является вопрос о характере взаимосвязей старообрядчества и рационалистического сектантства на Харьковщине. В XVIII в. регион был одним из центров распространения (а возможно - и местом зарождения) духоборчества ${ }^{78}$. При этом село Охочее, с которого началось распространение данного религиозного течения в регионе, издавна было одним из центров старообрядчества беспоповского направления. Именно среди местных старообрядцев духоборчество получило наибольшее распространение ${ }^{79}$. Из шести населённых пунктов Харьковского региона, в которых в конце XVIII в. были обнаружены духоборцы, четыре (Терновое, Охочее, Верхний Берек, Большие Проходы) были местами компактного проживания староверов-беспоповцев ${ }^{80}$. В конце XVIII в. лидеры духоборцев были выселены с территории Слобожанщины. Потеряв руководителей, обращенные из старообрядчества духоборцы довольно скоро забыли основные положения своей новой веры и вернулись на позиции беспоповского староверия ${ }^{81}$.

$\mathrm{B}$ начале $\mathrm{XX}$ в. появились признаки влияния нового течения рационалистического сектантства на староверов-беспоповцев Харьковской губернии. В «Отчете Харьковского епархиального совета по миссионерским делам за 1906 г.» отмечалось, что в среду беспоповцев Харьковской губернии проникли идеи штундизма. В частности, указывалось, что на миссионерских собеседованиях со старообрядцами Волчанского и Купянского уездов со стороны последних раздавались чисто штундистские замечания ${ }^{82}$. На рубеже XIX$\mathrm{XX}$ вв. старообрядцы Поморского согласия слободы Краснянки Купянского уезда начали образовывать штундистские кружки ${ }^{83}$. 
Таким образом, для беспоповцев Харьковской губернии была характерна склонность к сближению с рационалистическим сектантством (старорусским, как в случае с духоборчеством, или новым, как в случае со штундизмом). Потенциальная склонность приводила к реальному сближению, если для этого складывались благоприятные условия, в частности, со стороны рационалистических сект велась активная пропаганда. А она действительно имела место со стороны духоборцев во второй половине XVIII в. и штундистов во второй половине XIX - начале XX в. ${ }^{84}$

Следует отметить, что рационалистические тенденции среди беспоповцев имели место не только на территории Слободского края. Например, в конце XIX в. среди беспоповцев Южной Вятки возникли Евланино согласие (сторонники которого отрицали догмат о Святой Троице, молитвы перед иконами, возжигание свечей) и Никанорово согласие (основатель которого учил, что стоять на молитве и делать какие-либо внешние знаки излишне $)^{85}$. Характеризуя ситуацию по Российской империи в целом, публицист и знаток сектантства конца XIX - начала XX в. А.С. Пругавин писал: «беспоповщинский раскол раздробляется на множество толков и учений, из которых многие принимают явно рационалистическую окраску; таковы: немоляки, воздыханцы и т.д.» ${ }^{86}$.

Можно предположить, что, несмотря на различное вероучение, в народной среде беспоповское направление старообрядчества и рационалистическое сектантство казались схожими. Ведь при разной догматике, практические выводы староверов-беспоповцев и представителей рационалистического сектантства нередко совпадали: отсутствие иерархии и священства, упрощение обрядов, отказ от сакрализации существующей власти. Вероятно, именно эти внешние признаки, а не догматические тонкости, и бросались в глаза простому народу. Кроме того, рационалистическое сектантство сохраняло в себе элементы, которые сближали его со старообрядчеством. Относительно штундизма, остаётся открытым вопрос о том, в какой степени его можно считать интегральной частью развития Реформации, начавшейся в XVI в. в Западной Европе ${ }^{87}$. Миссионеры Русской Православной Церкви на рубеже XIX-XX вв. писали, что для штундистов характерно огромное внимание к внешним формам молитвы. Так, миссионер Иван Айвазов писал: «В любви к уставности и особенно служению «букве» он [штундист] не уступает раскольнику, хотя и кричит всюду о служении «духом» ${ }^{88}$. Более того, штундистские теологи заявляли, что крестное знамение является печатью антихриста, которую он наложил на руку и лоб ${ }^{89}$.

Вероятно, именно эти факты привели к лёгкому переходу части старообрядцев-беспоповцев Харьковского региона в духоборчество в конце XVIII в., а также проникновению идей штундизма в среду беспоповцев в начале XX в. В то же время не стоит преувеличивать размытость границ, разделявших старообрядчество и рационалистическое сектантство в Харьковском регионе. Ведь в конце XVIII в. имело место не слияние этих двух религиозных течений, а скорее краткосрочное поглощение одного течения другим на уровне нескольких сёл. Что же касается ситуации в беспоповщине на рубеже XIX - XX вв., здесь наблюдается лишь проникновение отдельных штундистских представлений в среду части старообрядцев-беспоповцев. Следует принять во внимание, что каждая форма религии, каждая конфессиональная группа содержит внутри себя множество различных интерпретаций вероучения своими собственными адептами ${ }^{90}$. Конечно, это в полной мере касалось и старообрядческих общин на территории Харьковщины. При этом, как было показано выше, несмотря на пестроту и размытость бытового восприятия веры старообрядцами, границы старообрядческих согласий, существовавших на Харьковщине в течение исследуемого периода, были достаточно устойчивыми и чёткими.

При этом границы старообрядчества как совокупности больших групповых сообществ не совпадали с границами, определёнными в материалах административно-полицейского и исповедного учёта. В Российской империи существовало значительное количество так называемых «тайных раскольников», которые были официально записаны как члены РПЦ, но считали себя древлеправославными христианами, принадлежали к старообрядческим общинам. Подобная ситуация была характерна и для Харьковщины. Так, купянский земский исправник в своём рапорте губернатору от 1858 г. писал: «при малейшем попустительстве ... раскол обнаруживается в большом количестве людей, ибо исповедующих в тайне раскол очень много ${ }^{91}$. Миссионер Северин Сулима в отчёте за 1864 г. отмечал, что староверы слободы Новая Николаевка Купянского уезда «давно тайно принадлежали к Поморской секте, а называли себя единоверцами, дабы избежать преследований и навяз- 
чивых увещеваний» ${ }^{92}$. Характеризуя ситуацию в целом по губернии, этот же миссионер в отчёте за 1878 г. отмечал, что когда старообрядцев преследовала духовная и гражданская власть, во избежание преследований они переходили в единоверие ${ }^{93}$.

Возникает вопрос, существовали ли в старообрядческих общинах внутренние границы, отделявшие официально зарегистрированных и тайных старообрядцев. К какому типу социальных общностей принадлежали эти две группы староверов? В Библии содержится прямой запрет на отречение от веры, пусть даже формальный: «А кто отречется от Меня пред людьми, отрекусь от того и Я пред Отцом Моим Небесным» (Мф. 10:33). Необходимо понять, каким образом старообрядцы совмещали сокрытие веры с этим запретом. Воспринималась ли ими формальная принадлежность к РПЦ (еретической, с точки зрения староверов) как предательство веры, или для подобных действий находились какие-то оправдания? Соответственно, имела ли место дискриминация тайных старообрядцев со стороны старообрядцев открытых и влияла ли разница между ними на социальную структуру старообрядческих общин?

Следует отметить, что феномен сокрытия веры среди старообрядцев Харьковской губернии в XIX - начале XX вв. имел сложный характер, происходил в соответствии с несколькими «моделями». Во времена правления Николая I особенно распространенными были случаи прямого давления на старообрядцев с целью склонить их к переходу в православие. Хотя право «природных старообрядцев» (то есть детей лиц, официально записанных старообрядцами) исповедовать свою веру официально не было отменено, разветвлённая и запутанная система мер, направленных на недопущение «совращения православных в раскол», давала возможность обвинить в их нарушении практически каждого старообрядца. Сторонники «старой веры» чаще всего привлекались к ответственности за распространение своей веры, а также за строительство новых и ремонт старых молитвенных домов $^{94}$, что было запрещено по законам Российской империи ${ }^{95}$.

В случае перехода в православие преследования старообрядцев прекращались ${ }^{96}$. Некоторые не выдерживали давления. Например, в 1840 г. в Канцелярии Харьковского губернатора велось дело о высылке в Закавказье крестьянки слободы Ольховатки Волчанского уезда Прасковьи Животовой (50 лет) «за совращение в раскол» дочери и внука. После того как Животова согласилась присоединиться к православию, её высылка была приостановлена ${ }^{97}$. В 1841 г., после двухмесячного пребывания в тюрьме за «повторное впадение в раскол», к единоверию присоединилась государственная крестьянка Марина Свечкарёва ${ }^{98}$. В 1855 г. старообрядческим наставникам села Райгородока Старобельского уезда было предложено отречься от своей веры и перейти в православие. Начетчик Афиноген Небесный не принял подобного предложения и на семь лет был заключён в тюрьму. Все остальные согласились и остались жить в деревне ${ }^{99}$. При этом, от новоприсоединённых требовали подписки такого образца: «Волчанского уезда Ольховатской волости хутора Кунина государственный крестьянин Яков Автономов Лащин, 19 лет, природный раскольник секты беспоповской, выражает намерение присоединиться к Православной Восточной Кафолической Церкви. Обязуюсь находиться в послушании к ней всегда» ${ }^{100}$.

Большинство подобных переходов осуществлялись лишь формально. Староверы, которые вследствие давления со стороны государства переходили в лоно РПЦ, как правило, продолжали тайно исповедовать «старую веру», о чем, в частности, свидетельствуют цитируемые выше миссионерские отчеты. Формальный переход в православие воспринимался как необходимое зло, уступка перед могуществом государственной машины. Староверы открыто стали заявлять об этом в конце 1850-х - начале 1860-х гг. на волне некоторого расширения их гражданских прав, а еще больше - слухов, порожденных отменой крепостного права. Как отметил В.П. Потоцкий, все уступки правительства объяснялись рядовыми старообрядцами как предоставление им полной свободы исповедания своей религии ${ }^{101}$. Когда в 1863 г. крестьянин хутора Ямполь В. Иванов (85 лет) вместе с семьей объявил себя старообрядцем, то на вопрос священника: «Недавно ты и твои сыновья клялись, что вы не староверы», он ответил: «Да тогда нельзя было делать иначе» ${ }^{102}$. Поселяне слободы Дробышевой долгое время придерживались старообрядчества тайно, однако в 1864 г. перестали ходить в православную церковь и устроили себе отдельную часовню. Когда местный православный священник стал упрекать старообрядцев, то один из староверов, Иван Ирков, заявил, что «теперь Государь всем позволил свободно переходить в раскол» ${ }^{103}$. В начале 1860 -х гг. в Чугуеве 66 человек, которые до того считались 
православными и даже давали подписки всегда находиться в РПЦ, перешли в Поморское согласие беспоповщины. При этом они заявляли, что могут исповедовать свою веру, потому что им, якобы, объявлена «милость Церкви» ${ }^{104}$.

Конечно, прямое отречение веры, пусть даже формальное, воспринималось староверами как грех, ведь многие из старообрядцев, несмотря на все меры властей, отказывались отречься от своей веры. В середине 1830-х гг., несмотря на уговоры священника Петра Акимова, благочинного протоиерея Петра Николаевского и уездного судьи Никиты Войтенкова, старообрядцы слобод Казачка, Уды и Лопань (всего - 358 человек) «остались непреклонными и упорными в своих заблуждениях», о чём дали соответствующую подписку $^{105}$. Старообрядцы слободы Лопань Панкратий Дигалов и Емельян Свичкарь, которые, среди прочих, дали такую подписку, в 1839 г. были сосланы в Закавказье «за повторное уклонение в раскол и соблазнение других к переходу в Поморскую секту» ${ }^{106}$. В 1840 г., несмотря на уговоры священника слободы Ольховатки Даниила Капустина, государственные крестьяне Григорий Марченко, Пелагея Крюкова и Степанида Пастухова отказались присоединиться к православию ${ }^{107}$.

Выше упоминалось о наставнике старообрядцев села Райгородока Афиногене Небесном, который отказался присоединиться к РПЦ и был заключён сроком на семь лет. В остроге содержался также уставщик старообрядческой общины слободы Ново-Николаевка Филипп Трубчанинов ${ }^{108}$. Миссионер Северин Сулима отмечал, что некоторые из староверов Харьковской губернии, отказываясь перейти в ряды РПЦ, заявляли, что «готовы хоть сейчас в ссылку» ${ }^{109}$.

Впрочем, далеко не всегда сокрытие веры старообрядцами было вызвано прямым давлением со стороны государства и РПЦ. Довольно часто оно было результатом стремления староверов легализовать свой семейный статус и статус своих детей. Ведь до 1874 г. старообрядцы могли официально зарегистрировать супружеские отношения, только обвенчавшись в храме РПЦ. В противном случае их брак не признавался, дети считались незаконно рождёнными. Кроме того, сочетаться браком с православными старообрядцы могли, только присоединившись к РПЦ ${ }^{110}$. В результате, старообрядцы Харьковщины нередко венчались в православных храмах и крестили там своих детей. Согласно рапорту Чугуевской военной канцелярии от 1816 г., подобная практика была распространена среди старообрядцев Поморского согласия города Чугуева. При этом, сразу после совершения венчания или крещения в православной церкви, староверы Чугуева осуществляли соответствующие обряды по правилам «старой веры» в своих молитвенных домах ${ }^{111}$. Это свидетельствует, что осуществляемые в храмах РПЦ таинства старообрядцы не считали действительными, проходя их только для официальной регистрации. Миссионер Северин Сулима в рапорте от 1875 г. отмечает, что некоторые старообрядцы «присоединились к православию с целью быть обвенчанными в церкви» ${ }^{112}$. При этом, по данным миссионера, старообрядцы, вступая в брак с православными, присоединялись к РПЦ, венчались в православном храме, но очень скоро снова возвращались в старообрядчество. Более того, в этом случае жёны староверов нередко также переходили в веру своих мужчин ${ }^{113}$.

Отношение старообрядцев Харьковщины к подобной практике было неоднозначным. Иногда она встречала осуждение и неприятие. Так, когда в 1810 г. харьковский купец-старообрядец Яков Косолапов присоединился к РПЦ, объясняя это стремлением жениться на православной, его мать воспротивилась такому решению сына и угрожала лишить его наследства ${ }^{114}$. В 1858 г. некоторые старообрядцы слободы Наугольновки, ранее скрывавшие свою веру, открыто заявили о принадлежности к старообрядчеству и категорически отказались крестить своих детей в храме РПЦ ${ }^{115}$. Подобное отношение староверов к участию в совместной молитве с духовенством еретической, по их мнению, церкви понятно. Однако такой ригористический подход не был всеобщим среди старообрядцев Харьковщины. В рапорте Чугуевской военной канцелярии от 1816 г. практика венчаний местных староверов в храмах РПЦ описана как общепринятая ${ }^{116}$. Таким образом, её можно рассматривать как социальную норму среди староверов Чугуева, если не на уровне нормы как идеала (из-за противоречий подобной практики и канонических положений), то на уровне нормы статистической - модели поведения, принятой большинством лиц в определенной общности $^{117}$. Характерным является пример Сидора Коренева (умер в 1849 г.), который был записан как член РПЦ, в возрасте 13 лет был на исповеди у новообрядческого священника, 
все дети Коренева (12 человек) были крещены в храме РПЦ. Тем не менее, он был избран наставником старообрядческой общины села Боровая ${ }^{118}$.

При этом следует различать участие староверов в обрядах РПЦ для регистрации своего семейного статуса и сам факт их записи в документах духовной консистории как православных. В Российской империи до 1905 г. выход из РПЦ был запрещен, право исповедовать старообрядчество имели только «природные раскольники», то есть потомки староверов $^{119}$. Поэтому в списки старообрядцев, составлявшиеся местной полицией, начиная с 1811 г., вносились только приверженцы «старой веры», предки которых были официально записаны раскольниками в XVIII в. ${ }^{120}$ Официально зарегистрированный старообрядец, однажды записанный среди православных (например, обвенчавшись в православном храме), тоже не мог быть снова «записан в раскол». Если он крестил своего ребенка в РПЦ, этот ребенок считался православным. Даже в случае, если власти становилось известно, что член РПЦ перешёл в старообрядчество (зачастую это просто означало, что реальная конфессиональная принадлежность старообрядца стала известной), этого человека не вносили в список раскольников ${ }^{121}$.

Наставник старообрядческой общины села Ольховатка Волчанского уезда Никифор Орлов в ходатайстве к Харьковской духовной консистории (1854) отмечал, что «хотя некоторые происходящие из природных старообрядцы и были в прежние времена крещены и венчаны в Православной Церкви, то это происходило по нужде, ... но оные старообрядцы никогда в сущности не присоединялись к Православной Церкви и далее общения с нею не имели» ${ }^{122}$. Следовательно, разница между официально зарегистрированными и «тайными» старообрядцами не отражалась на социальной структуре старообрядческих общин. Если отречение веры, а иногда и участие в обрядах РПЦ для регистрации своего семейного положения, воспринимались староверами как предательство веры, то нахождение в официальных списках верующих РПЦ, само по себе, не считалось таковым.

Таким образом, тайные и официально зарегистрированные старообрядцы представляли собой номинальные социальные общности. Разница между ними существовала не на уровне внутренней иерархии в общине, а на уровне их юридического статуса. Официально зарегистрированные старообрядцы были ограничены в правах, особенно, во времена Николая I ${ }^{123}$. Это было ещё одной причиной сознательного сокрытия своей веры частью староверов. Кроме того, в условиях государственного давления на старообрядчество нередко было спокойнее скрывать свою принадлежность к религиозному диссидентству ${ }^{124}$. Однако по закону зарегистрированные в «раскольнических ведомостях» старообрядцы не преследовались за свои религиозные убеждения. Те же староверы, которые в материалах исповедного и полицейского учета были записаны как православные, не имели возможности открыто заявить о своей вере, так как выход из РПЦ был запрещен. Правда, российское законодательство предусматривало уголовную ответственность только для человека, «соблазнившего» православного перейти в раскол. Сам же «совращенный» только подлежал трехкратному «увещеванию» в духовной консистории ${ }^{125}$. Если после консисторских собеседований человек отказывался вернуться в РПЦ, с него брали подписку никого не совращать в раскол. Однако подобные беседы в консистории приносили серьезные убытки лицу, с которым они велись. Ведь на время общения с консисторскими чиновниками старовер отрывался от своего хозяйства ${ }^{126}$.

Конечно, на местном уровне старообрядцы, официально записанные как православные, благодаря распространенной практике взяточничества обычно находили пути предотвращения преследований ${ }^{127}$. Однако это не означает, что тайные старообрядцы были гарантированы от притеснений. Местная полиция всегда могла начать следствие против них. Характерно, что уже упоминавшийся Никифор Орлов несколько раз привлекался к суду за «совращение православных в раскол» ${ }^{128}$. В частности, в 1851 г. он был арестован за то, что, якобы, «совратил» свою жену Марью в «раскол». В ходе следствия выяснилось, что и Никифор, и Марья Орловы с детства исповедовали «старую веру». Однако Марья в детстве была крещена в православной церкви, и поэтому официально считалась православной. А значит, и ее исповедание «старой веры» квалифицировалось как «совращение православной в раскол» ${ }^{129}$. Понятно, что в таких условиях тайные старообрядцы были заинтересованы, чтобы их конфессиональная принадлежность была официально зафиксирована. Именно об этом просил Никифор Орлов в цитированном выше ходатайстве Харьковской консистории ${ }^{130}$. Но существующая правовая система не давала такой возможности. 
Таким образом, старообрядчество Российской империи в течение XIX - начала XX в. представляло собой номинальную социальную общность (или социальную категорию), частью которой были староверы Харьковщины. При этом в пределах старообрядчества существовали реальные социальные группы (так называемые толки и согласия). Как и любые крупные групповые общности, они могут быть охарактеризованы как воображаемые сообщества (в терминологии Бенедикта Андерсона). Характер представления староверов о своей принадлежности к тому или иному согласию может быть охарактеризован как двухуровневый. Теоретически сформулированные элитой старообрядческих согласий экклезиологические идеи далеко не всегда проникали в среду рядовых староверов Харьковщины. Их единство с согласием проявлялось через принадлежность к конкретной старообрядческой общине (малой или средней социальной группе), которая была организационно и на уровне представлений связана с другими при посредничестве своих лидеров и хорошо образованных членов. Для беспоповцев Харьковской губернии была характерна склонность к сближению с рационалистическим сектантством, что, в частности, проявилось в проникновении штундистских идей в беспоповство на рубеже XIX - XX вв. Однако эта склонность осталась на уровне бытового восприятия веры некоторыми старообрядцами, поэтому границы старообрядческих согласий, как воображаемых сообществ, были достаточно чёткими. Среди староверов Харьковщины существовала довольно большая группа тех, кто исповедовал веру тайно. Сокрытие веры старообрядцами происходило по разным «моделям», которые по-разному воспринимались староверами. Отречение веры осуждалось, хотя под давлением со стороны государства старообрядцы иногда шли на него, как на вынужденное зло. Участие в таинствах РПЦ для официальной регистрации своего семейного положения часть древлеправославных, в полном соответствии с канонами, считала грехом, однако в некоторых общинах подобная практика стала социальной нормой. Что же касается самих фактов нахождения в списках верующих РПЦ, они не воспринимались староверами как измена и не создавали внутренних границ в старообрядческих общинах.

1 Димитрий Ростовский (Туптало), мир. Розыск о раскольнической брынской вере. - М., 1855. - С. 588-610; Андрей Иоаннов (Журавлёв), прот. Полное историческое известие о древних стригольниках и новых раскольниках, так называемых старообрядцах. - В 4-х частях. - Ч. 2. - СПб., 1855. - C. 1-73.

${ }^{2}$ См., напр.: Щапов А.П. Русский раскол старообрядчества. - Казань, 1859. - С. 263-289; Липранди И.П. Краткое обозрение существующих в России расколов, ересей и сект, как в религиозном, так и в политическом их значении // Сборник правительственных сведений о раскольниках / Сост. В. Кельсиевыв. - Вып. 2. - Лондон, 1861. - С. 99-139; Мельников П.И. Письма о расколе // Собр. соч. - Т. 6. - М., 1963. - С. 213-243; Милюков П.Н. Очерки по истории русской культуры. СПб., 1897. - С. 90; Кириллов И.А. Статистика старообрядчества. - М., 1913. - С. 5-25.

${ }^{3}$ Колесник I.I. «Міждисциплінарність» як концепт I. I. Колесник // Харківський історіографічний збірник / Харьковский историографический сборник. - 2008. - Вип. 9. - С. 23-34.

${ }^{4}$ Шахов М.O. К проблеме содержания понятия «старообрядчество». - URL: http://samstarbiblio.ucoz.ru/publ/146-1-0-1032 (дата обращения: 01.02.2015); Эткинд А. Хлыст (Секты, литература и революция). - М., 1998. - С. 33; Панченко А.А. Христовщина и скопчество: Фольклор и традиционная культура русских мистических сект. - 2-е изд. - М., 2004. - С. 131, 146, 243; Солдатов A.A. Локальное и глобальное в идентичности старообрядцев-беспоповцев (по материалам экспедиций в регион Южной Вятки) // Культурные границы и границы в культуре (материалы конференции молодых учёных. Москва, 5-7 декабря 2012 г.). - М.: ИЭА РАН, 2013. - С. 20-27; Клибанов А.И. Народные противоцерковные движения // Русское православие: вехи истории / Науч. ред. А.И. Клибанов. - М., 1989. - С. 568-569.

${ }_{5}^{5}$ Аринин Е.И. Религиоведческая методология перед вызовом старообрядческой идентичности // «А мне глаголати не леностно...»: раскол и старообрядчество в современной рефлексии (сборник науч. тр.) / Под ред. И.А. Едошина. - Кострома: КГУ им. Н.А. Некорасова, 2012. - С. 141.

${ }^{6}$ Князева Е.H. Трансдисциплинарные стратегии исследований // Вестник ТГПУ / TSPU Bulletin. - 2011. - № 10 (112). - С. 194.

${ }^{7}$ Шахов M.O. К проблеме содержания понятия «старообрядчество». - URL: http://samstar-biblio. ucoz.ru/publ/146-1-0-1032 (дата обращения: 01.02.2015).

${ }^{8}$ Новикова C.C. Социология: история, основы, институционализация в России. - URL: http:// www.gumer.info/bibliotek_Buks/Sociolog/Novik/index.php (дата обращения: 05.02.2015). 
${ }^{9}$ Аринин Е.И. Религиоведческая методология... - С. 141-146.

${ }^{10}$ Новикова C.C. Социология: история, основы, институционализация в России. - URL: http:// www.gumer.info/bibliotek_Buks/Sociolog/Novik/index.php

${ }^{11}$ Щапов А.П. Русский раскол старообрядчества... - С. 287-289.

${ }^{12}$ См.: Мальизев А.И. Старообрядческие беспоповские согласия в XVIII - начале XIX вв.: проблема взаимоотношений. - Новосибирск, 2006. - 572 с.

${ }^{13}$ Костров A.B. Развитие концепции старообрядчества в официально-церковном и старообрядческом направлениях отечественной историографии во второй половины XIX - начала XX вв. URL: http:/www.dissercat.com/content/razvitie-kontseptsii-staroobryadchestva-v-ofitsialno-tserkovnomi-staroobryadcheskom-napravl (дата обращения: 05.02.2015).

${ }^{14}$ Ильин В.И. Феномен поля: от метафоры к научной категории // Рубеж (альманах социальных исследований). - 2003. - № 18. - С. 46-49.

${ }^{15}$ Новикова С.С. Социология: история, основы, институционализация в России. - URL: http:// www.gumer.info/bibliotek_Buks/Sociolog/Novik/index.php

${ }_{16}$ Согласие (соглас) // Российский гуманитарный энциклопедический словарь. - М.: Гуманит. изд. центр ВЛАДОС, 2002. - URL: http://slovari.yandex.ru/ (дата обращения: 05.02.2015).

${ }_{17}$ Шахов M.O. Философские аспекты староверия. - URL: http://starajavera.narod.ru/ (дата обращения: 20.01.2015).

${ }_{18}$ Андерсон Б. Уявлені спільноти: Міркування щодо походження й поширення націоналізму. Київ, 2001. - С. 23.

${ }^{19}$ Распределение старообрядцев и сектантов по толкам и сектам / Сост. Центр. Стат. комитетом Мин-ва внутр. дел по данным первой всеобщей переписи 1897 г. - СПб., 1901. - С. 4-7.

${ }^{20}$ Браилавский Л.Ю. Религиозные и оккультные движения в Чувашии (культы, церкви, секты, деноминации, духовные школы). - Чебоксары, 2000. - С. 66.

${ }^{21}$ Pentikainen J. The priestless Pomorrsy in the Baltic Area: Old Believer Communities on the Western Coast of Lake Peipus // «Silent as Waters we Live»: Old Believers in Russia and Abroad: Cultural Encounter with the Finno-Ugrians / Ed. by Yuha Pentikainen. - Studia Fenica. Folcloristica 6. - Helsinki: Finnish Literature Society, 2000. - P. 90.

${ }^{22}$ Гиляров-Платонов Н.П. Вопросы веры и церкви. - Т. 1. - М., 1905. - С. 15.

${ }^{23}$ Пригарин A.A. Русские старообрядцы на Дунае: формирование этноконфессиональной общности в конце XVIII - первой половине XIX вв. - Одесса-Измаил-Москва, 2010. - С. 275.

${ }^{24}$ Государственный архив Харьковской области (далее - ГАХО), ф. 40, оп. 110, д. 2051, л. $26-27$.

${ }^{25}$ ГАХО, ф. 40, оп. 70, д. 737, л. 32.

26 Там же, л. 33.

${ }^{27}$ ГАХО, ф. 40, оп. 71, д. 2087, л. 4-5.

${ }^{28}$ Там же.

29 Эткинд А. Хлыст... - С. 108.

${ }^{30}$ ГАХО, ф. 40, оп. 71, д. 2087, л. 5.

${ }^{31}$ ГАХО, ф. 40 , оп. 81 , д. 208, л. 36.

${ }^{32}$ ГАХО, ф. 3 , оп. 103 , д. 47 , л. 104.

${ }^{33}$ ГАХО, ф. 3, оп. 195, д. 117, л. 15.

34 Потоцький В.П. Релігійне сектантство в Харківській губернії (1861-1917): дис. ... канд. іст. наук. - Харків, 2004. - С. 53-54.

35 Филарет (Гумилевский), архиеп. Историко-статистическое описание Харьковской епархии. Т. 3. - Харьков, 2006. - С. 108-109.

${ }^{36}$ ГАХО, ф. 40, оп. 70, д. 737 , л. 30-а.

${ }^{37}$ ГАХО, ф. 40, оп. 71, д. 2087, л. 5.

${ }^{38}$ ГАХО, ф. 3 , оп. 272 , д. 196, л. 54.

${ }^{39}$ ГАХО, ф. 40, оп. 70, д. 737 , л. 32.

${ }^{40}$ ГАХО, ф. 40, оп. 71, д. 2087, л. 5.

${ }^{41}$ Таранец С.B. Старообрядчество в Российской империи (конец XVII - начало XX века). - T. 1: Взаимоотношения старообрядческих сообществ с государством и официальной Церковью. - К., 2012. - C. 378-379.

42 Кормчая, напечатанная с оригинала патриарха Иосифа. - М., 1912 (1650). - С. 139.

43 Подсчитано по данным: Первая Всеобщая перепись населения Российской Империи 1897 г. / Под ред. Н.А. Тройницкого. - Т. 46. Харьковская губерния. - СПб., 1904. - С. 106.

${ }_{44}$ Там же.

${ }^{45}$ Керов В.В. «Самые вредные сектаторы»: социоконфессиональная роль женщин в старообрядческом образовании XIX - начала XX вв. // Женщины и мужчины в контексте исторических перемен. - Т. 1 / Отв. ред.: А.В. Белова, Н.Л. Пушкарева. - М., 2012. - С. 346-349.

46 Прігарін O.A. Формування етноконфесійної спільноти росіян-старообрядців у Нижньому Подунав'ї (друга половина XVIII - перша половина XIX ст.): автореферат дис. ... докт. іст. наук. Чернівці, 2015. - С. 26. 
${ }^{47}$ Поздеева И.В. 40 лет полевых археографических исследований Московского университета: педагогика, практика, теория // Традиционная книга и культура позднего русского средневековья (труды Всероссийской научной конференции к 30-летию полевых археографических исследований Московского государственного университета им. М.В. Ломоносова, Москва, 27-28 октября 2006 г.) / Под ред. И.В. Поздеевой. - Ч. 1: Кириллическая книга в русской истории и культуре. - Ярославль, 2008. - С. 37.

${ }^{48}$ Мельникова E.A. Библия в сельской России: практики чтения и способы воображения. - URL: http://historians.in.ua/index.php/doslidzhennya/464-ekateryna-melnykova-byblyia-v-selskoi-rossyypraktyky-chtenyia-y-sposoby-voobrazhenyia-chast-1 (дата обращения: 15.10.2015).

${ }^{49}$ См.: Мальцеев А.И. Старообрядческие беспоповские согласия...- С. 19.

50 Tаранец C.B. Старообрядчество в Российской империи (конец XVII - начало XX века). - T. 2 : Старообрядчество в социокультурном контексте. - К., 2013. - С. 270.

51 Андерсон Б. Уявлені спільноти: Міркування щодо походження й поширення націоналізму. Київ, 2001. - С. 57.

${ }^{52}$ Robson R. Old Believers in Modern Russia. - DeKalb, 1995. - P. 10-13.

${ }^{53}$ Crummey R. Old Belief as Popular Religion: New Approaches // Slavic Review. - 1993. - Vol. 52. - № 4. - P. 708 .

${ }^{54}$ ГАХО, ф. 3, оп. 103, д. 47, л. 105-117.

${ }^{55}$ ГАХО, ф. 3, оп. 110, д. 71, л. 64; ГАХО, ф. 40, оп. 24, д. 803, л. 1.

${ }^{56}$ ГАХО, ф. 40, оп. 110, д. 2051, л. 10.

${ }^{57}$ ГАХО, ф. 40 , оп. 70, д. 737 , л. 30-а.

58 Там же, л. 33.

${ }^{59}$ ГАХО, ф. 3 , оп. 67 , д. 201 , л. 49.

${ }^{60}$ ГАХО, ф. 40, оп. 71, д. 2087, л. 5; ГАХО, ф. 40, оп. 97, д. 1051, л. 18.

${ }^{61}$ Потоиький В.П. Релігійне сектантство... - С. 176.

${ }^{62}$ Таранеи С.В. Старообрядчество... - С. 260-261.

${ }^{63}$ ГАХО, ф. 3, оп. 71, д. 249, л. 1.

${ }^{64}$ ГАХО, ф. 3, оп. 272, д. 196, л. 33-36.

${ }^{65}$ ГАХО, ф. 40, оп. 71, д. 2087, л. 33-34.

${ }^{66}$ Харьковский календарь на 1896 год с приложением. - Харьков, 1896. - С. 80.

${ }^{67}$ ГАХО, ф. 40, оп. 71, д. 2087, л. 3-4.

${ }^{68}$ ГАХО, ф. 40, оп. 110, д. 2051, л. 19-20.

${ }^{69}$ Там же.

${ }^{70}$ ГАХО, ф. 40, оп. 81, д. 208, л. 36-39.

${ }^{71}$ ГАХО, ф. 40, оп. 71, д. 2087, л. 4.

${ }^{72}$ ГАХО, ф. 40, оп. 81, д. 208, л. 36-39.

${ }^{73}$ Новикова C.C. Социология: история, основы, институционализация в России. - URL: http:// www.gumer.info/bibliotek_Buks/Sociolog/Novik/index.php (дата обращения: 05.02.2015).

${ }^{74}$ Мельников П.И. Письма о расколе // Собр. соч. - Т. 6. - М., 1963. - С. 242-243; Кириллов И.А. Статистика старообрядчества. - М., 1913. - С. 4-5.

75 Эткинд А. Хлыст......- С. 33; Панченко А.А. Христовщина и скопчество... - С. 131, 243.

76 Романова E.B. Проблемы изучения массовых самоубийств старообрядцев в исследованиях $\mathrm{XIX} \mathrm{-} \mathrm{XX} \mathrm{вв.} \mathrm{//} \mathrm{Антропология,} \mathrm{фольклористика,} \mathrm{лингвистика} \mathrm{(сборник} \mathrm{статей).} \mathrm{-} \mathrm{Вып.} \mathrm{1.} \mathrm{-} \mathrm{СПб.,}$ 2001. - C. 65-66.

77 Панченко А.А. Христовщина и скопчество... - С. 128; Эткинд А. Хлыст... - С. 33.

${ }_{78}^{78}$ Букевич Т.И. Обзор русских сект и их толков. - Харьков, 1910. - С. 209.

79 Филарет (Гумилевский), архиеп. Историко-статистическое описание Харьковской епархии. Т. 3. - Харьков, 2006. - С. 124.

${ }^{80}$ ГАХО, ф. 3, оп. 67, д. 235, л. 180-182; ГАХО, ф. 3, оп. 79, д. 269, л. 51-55; ГАХО, ф. 3, оп. 87, д. 25, л. 2-4; ГАХО, ф. 3, оп. 175, д. 260, л. 29-35.

81 Филарет (Гумилевский), архиеп. Историко-статистическое описание Харьковской епархии. T. 3. - Харьков, 2006. - С. 124.

${ }^{82}$ ГАХО, ф. 40, оп. 71, д. 2087, л. 6.

83 Потоцький В.П. Релігійне сектантство... - С. 115.

${ }^{84}$ Новицкий О.М. Духоборцы. Их история и вероучение. - Киев, 1882. - С. 19-23; Потоцьький В.П. Релігійне сектантство... - С. 87-88.

${ }^{85}$ Материалы к истории старообрядчества Южной Вятки. По итогам комплексних археографических экспедиций МГУ имени М. В. Ломоносова (сб. документов) / Отв. ред. В.П. Богданов. - М., 2012. - С. 61-64. - C. 21

${ }^{86}$ Пругавин А.С. Раскол внизу и раскол вверху: Очерки современного сектантства. - СПб., 1882.

87 Дискуссии по данному вопросу см.: Zhuk S. Russia’s Lost Reformation. Peasants, Millennialism, and Radical Sects in Southern Russia and Ukraine, 1830-1917. - Washington, 2004. - 457 р.; Савченко С. 
Чи втратила Росія Реформацію? Історико-теологічний коментар до однієї теорії // Україна модерна. - 2010. - № 6. - С. 195-248.

${ }^{88}$ Савченко С. Чи втратила Росія Реформацію... - С. 226.

${ }^{89}$ Цит. по.: Савченко С. Чи втратила Росія Реформацію...-С. 219.

${ }^{90}$ Аринин Е.И. Философия религиозности. Академическое введение в основные концепции и термины / Е.И. Аринин, Н.М. Маркова. Владимир, 2010. - С. 41-42.

${ }^{91}$ ГАХО, ф. 3, оп. 195, д. 117 , л. 2.

${ }^{2}$ Потоикий В.П. Очерк истории старообрядчества Харьковской губернии // Липоване: история и культура русских старообрядцев. - 2008. - Вып. 5. - С. 79.

${ }^{93}$ ГАХО, ф. 3, оп. 272, д. 196, л. 33-36.

${ }^{94}$ ГАХО, ф. 3, оп. 127, д. 62, л. 1-5; ГАХО, ф. 3, оп. 147, д. 287-б, л. 1-34; ГАХО, ф. 3, оп. 155 , д. 56-а, л. 1-42.

95 Полное собрание законов Российской империи. - Собр. 2-е. - Т. 14. - Отд. 1-е. - СПб., 1831. - C. 302 .

${ }^{96}$ Полное собрание законов Российской империи. - Собр. 2-е. - Т. 19. - Отд. 1-е. - СПб., 1845. - C. 213

${ }^{97}$ ГАХО, ф. 3, оп. 123 , д. 62 , л. 1-10.

${ }^{98}$ ГАХО, ф. 3, оп. 127, д. 1, л. 5.

${ }^{99}$ Потоцький В.П. Релігійне сектантство... - С. 49.

100 Там же.

${ }^{101}$ Там же. - С. 53.

102 Там же. - C. 54.

${ }^{103}$ ГАХО, ф. 3, оп. 215, д. 278, л. 1-25.

${ }^{104}$ Потоцький В.П. Релігійне сектантство... - С. 54.

${ }^{105}$ ГАХО, ф. 3, оп. 103, д. 47, л. 95.

${ }^{106}$ ГАХО, ф. 3, оп. 119, д. 53, л. 1-30.

${ }^{107}$ ГАХО, ф. 3, оп. 123, д. 62, л. 1-10.

${ }^{108}$ ГАХО, ф. 3, оп. 272, д. 196, л. 33-36.

${ }^{109}$ ГАХО, ф. 3, оп. 257, д. 197, л. 345-346.

${ }^{110}$ ГАХО, ф. 1473, оп. 1, д. 54, л. 66-73.

${ }^{111}$ ГАХО, ф. 3, оп. 32, д. 260, л. 34-55.

${ }^{112}$ ГАХО, ф. 3, оп. 257, д. 197, л. 345-346.

113 Там же.

${ }^{114}$ ГАХО, ф. 3, оп. 17, д. 218, л. 1-2.

${ }^{115}$ ГАХО, ф. 3, оп. 215, д. 91, л. 4-6.

${ }^{116}$ ГАХО, ф. 3, оп. 32, д. 260, л. 34.

117 Смирнова Е.Э. Социальная норма и возможности её измерения / Е.Э. Смирнова, В.Ф. Курлов, М.Д. Матюшкина // Социологические исследования. - 1999. - № 1. - С. 97-101.

${ }_{118}$ Филарет (Гумилевский), архиеп. Историко-статистическое описание Харьковской епархии. Т. 3. - Харьков, 2006. - С. 120.

119 Уложение о наказаниях уголовных и исправительных. - СПб., 1845. - С. 66-73.

${ }^{120}$ Мельников П.И. Счисление раскольников // Полное собр. соч. - 2-е изд. - Т. 7. - СПб., 1909. - C. 391.

${ }^{121}$ Мельников П.И. Счисление... - С. 396.

${ }^{122}$ ГАХО, ф. 40 , оп. 40, д. 865 , л. 1-4.

${ }^{123}$ Таранеи С.B. Старообрядчество в Российской империи... - С. 272.

${ }^{124}$ Иванов К.Ю. Проблемы учета старообрядцев на территории Кузбаса. - URL: http://konstanivanov.narod.ru/Articles1997-2.html (дата обращения: 03.02.2015).

${ }^{125}$ Полное собрание законов Российской империи. - Собр. 2-е. - Т. 16. - Отд. 1-е. - СПб., 1831. - C. 224

${ }^{126}$ Мельников П.И. Счисление... - С. 396.

${ }_{127}$ Керов В.В. Предприниматели-старообрядцы и взяточничество в России XIX в.: элементы деловой культуры или гражданская коррупция? // Wschodni Roszhik Humanistyczny. - 2012. - T. 8. C. $141-161$.

${ }^{128}$ ГАХО, ф. 3, оп. 155, д. 56-а, л. 30; ГАХО, ф. 3, оп. 175, д. 275-а, л. 1-10.

${ }^{129}$ ГАХО, ф. 3, оп. 155, д. 56-а, л. 30.

${ }^{130}$ ГАХО, ф. 40, оп. 40, д. 865, л. 1-4. 